\title{
CHALLENGES OF SCIENTIFIC PUBLICATION FOR THEOLOGICAL ACADEMICS IN INDONESIA
}

\author{
Wahyudin Darmalaksana ${ }^{1}$ dan Busro ${ }^{2}$ \\ ${ }^{1,2}$ Fakultas Ushuluddin UIN Sunan Gunung Djati Bandung \\ email: yudi_darma@uinsgd.ac.id
}

\begin{abstract}
ABSTRAK
Penelitian ini berangkat dari suatu kegelisahan akademik mengapa publikasi ilmiah bidang teologi Islam mengalami ketertinggalan yang sangat jauh dari bidang sains dan teknologi yang akseleratif. Sehingga melalui penelitian kualitatif berusaha ditelusuri sebab-sebabnya untuk ditemukan solusinya melalu pelaksanaan focus group discussion. Hasil pembahasan menunjukan bahwa teologi Islam berbasis pada materi dasar Islam, sedangkan sains dan teknologi mengembangkan materi terapan yang menjadi arah kebijakan dunia internasional. Penelitian ini menyimpulkan bahwa belum ada titik temu secara signifikan antara teologi Islam dan sains. Karenanya dikekomendasikan perlu adanya teori yang terhubung dengan realitas dalam konstruksi teori abstrak teologis Islam, teori pertengahan hasil formulasi pemikiran, dan teori aplikatif yang bersifat terapan, sedangkan pengembangan konstruksi ini dimungkinkan melalui kolaborasi antara akademisi teologi Islam dan akademisi sains. Direkomendasikan pula agar pengampu kebijakan memberikan perhatian bagi pengembangan teologi Islam muti-disipliner dan trans-disipliner. Berdasarkan hal ini diprediksi teologi Islam dan sains menjadi seiring dan sejalan dalam akselerasi publikasi di jurnal ilmiah.
\end{abstract}

Kata kunci: publikasi ilmiah, Sains dan teknologi, Teologi Islam

\section{A. INTRODUCTION}

Sains merupakan kiblat publikasi ilmiah. Meskipun berada di dalam lingkungan pendidikan tinggi keagamaan, namun sains dan teknologi memimpin publikasi ilmiah (Murtadlo, 2020). Ini merupakan kasus di Universitas Islam Negeri (UIN) Sunan Gunung Djati Bandung, Indonesia (Darmalaksana, 2019a). Sebagai perbandingan (Kurniasih et al., 2018), pun pula di Universitas Indonesia, yang populer sebagai pendidikan tinggi basis sosial dan humaniora, ternyata bidang sains paling produktif dalam publikasi ilmiah bereputasi internasional. Publikasi ilmiah merupakan sarana aktualisasi akademisi dan peningkatan harga diri negara (Subekti, 2018). Juga tolak ukur tercapainya Tri Dharma dan barometer kredibilitas serta kualitas pendidikan tinggi (Jannah, 2018). Tegaslah, penguatan publikasi ilmiah di pendidikan tinggi merupakan subjek yang mendesak. Pertanyaannya, bagaimana meningkatkan publikasi ilmiah bidang teologi Islam yang berfokus pada pengetahuan dasar agama.

Sejumlah peneliti telah menganjurkan beberapa hal. Di antaranya perlu arah kebijakan (Yamin, 2018), tata kelola dan strategi (Sugilar et al., 2019), pemetaan dan penguatan kapasitas sumber daya (Junipriansa, 2020), dan pendanaan serta 
penghargaan (Subekti, 2018). Pentingnya mengadakan pusat penulisan (Gray \& Hoyt, 2020; Lobner \& As, n.d.; Petrykowski, 2020; Schell-Barber, 2020; Siemann, 2020). Sosialisasi (Triyanto et al., 2020), pelatihan (Falah, 2019; Fernandez et al., 2020; Firmansyah et al., 2020; Ina \& Yulianti, 2020; Mardin et al., 2020; Perdana, 2020; Suratman \& Eriyanti, 2020), (Triyanto et al., 2020), workshop (Fadhilaturrahmi et al., 2020; Putra \& Saputra, 2019), dan lain-lain. Materi latihan mencakup hal prinsip (Adnan, 2005; Wekke, 2019), strategis (Murtadlo, 2020), dan teknis (Situmorang \& Sihombing, 2018). Ada pula anjuran penguatan dalam pengelolaan jurnal ilmiah (Asmiati, 2020). Dianjurkan pula kolaborasi dalam penulisan artikel ilmiah (López-Pellisa et al., 2020; Maryono \& Surajiman, 2017; McMillan et al., 2020; Rahmawati \& Thalia, 2012; Rosa et al., 2020; Viale Pereira et al., 2017).

Teologi dipahami sebagai rumpun pengetahuan dasar agama (Badarussyamsi, 2015; Basri, 2019). Penelitian teologi bersifat normatif (Muhajir, 2018) hingga mengalami perkembangan dalam bentuk teologi sosial (Rakhman, 2013), teologi sains yang bersifat saintifik (Badarussyamsi, 2015; Basri, 2019), dan teologi terapan (Syukur, 2003). Pendidikan Tinggi Keagamaan Islam (PTKI) mengembangkan integrasi ilmu antara agama dan sains (Darda, 2016; Istikomah, 2019; Lukman, 2017; Mahmud \& Arafah, 2020; Nugraha, 2020; Saifudin, 2020; Suharto, 2018; Suryadilaga, 2007; Tim Penyusun, 2019; Zainiyati, 2015). Integrasi agama dan sains dikenal dengan paradigama Wahyu Memandu Ilmu (WMI) Di UIN Sunan Gunung Djati Bandung Wahyu memandu ilmu (N F Natsir, 2013; Nanat Fatah Natsir, 2006). Seiring dengan alih status dari Institut Agama Islam (IAIN) ke UIN, implementasi integarasi ilmu diupayakan di PTKI (Aziz, 2013; Bahri, 2012; Kartimi \& Mulyani, 2016; Misbah, 2019; Mujahidah \& Wekke, 2019; Mujiburrahman, 2017; Muksin, 2019; Raya, 2017). Pengembangan teologi Islam merupakan konsekuensi akadomasi metodologi dengan pendekatan ilmu-ilmu sosial (Hasbiansyah, 2008; Lubis, 2015; Mahyudi, 2016; Shodiq, 2018) dan ilmu alam (Afwadzi, 2016, 2017) dalam mewujudkan penelitian inter-disipliner, multi-disipliner, dan trans-disipliner (Rohmatika, 2019; Sudikan, 2015).

Bidang teologi Islam masih menghadapi tantangan berat publikasi ilmiah. Diakui sains dan teknologi sedang memimpin publikasi ilmiah (Darmalaksana, 2019a; Murtadlo, 2020). Penggalian hingga ke akar masalah perlu dilakukan, sehingga 
ditemukan solusi mengatasi tantangan publikasi ilmiah di lingkungan akademisi teologi Islam.

\section{B. RESEARCH METHOD}

Penelitian ini merupakan jenis kualitatif (Anggito \& Setiawan, 2018) yang melakukan penggalian data melalui studi pustaka dan studi lapangan (Darmalaksana, 2020). Penelitian ini merupakan studi kasus di Fakultas UIN Sunan Gunung Djati Bandung, Indonesia. Adapun pemecahan masalah dilakukan melalui Focus Group Discussion (FGD).

\section{DISCUSSION}

\section{Existence of Theological Academics}

Akademisi teologi merupakan himpunan peminat ilmu-ilmu keagamaan. Ia dibedakan dengan peminat sains dan teknologi. Akademisi meliputi dosen dan mahasiswa. Bidang teologi berada dalam lingkup universitas, meskipun pendidikan tinggi tersebut berbasis keagamaan Islam. Akademisi teologi di UIN Sunan Gunung Djati berada pada Fakultas Ushuluddin. Sebagai fakultas paling tua yang berdiri tahun 1968 (Penyusun, 2019).

Pada 2021, fakultas ini memiliki lima program studi (Penyusun, 2019), yakni Jurusan Aqidah dan Filsafat Islam (AFI), Jurusan Studi Agama-Agama (SAA),
Jurusan Ilmu Al-Qur'an dan Tafsir (IAT), Jurusan Ilmu Hadis (ILHA), dan Jurusan Tasawuf dan Psikoterapi (TP). Program studi berperan mengembangkan kurikulum dan pengelolaan akademik. Di masingmasing program studi terdapat laboratorium yang dikoordinasi oleh laboratorium fakultas. Selebihnya, fakultas ini mengelola enam jurnal ilmiah (Penyusun, 2019). Pertama, Jurnal Wawasan dengan fokus kajian keislaman dan sosial budaya. Kedua, Jurnal Al-Bayan berfokus pada kajian AlQur'an dan Tafsir. Ketiga, Jurnal Religious dengan fokus kajian agama-agama dan lintas budaya. Keempat, Jurnal Diroyah berfokus pada kajian Ilmu Hadis. Kelima, Jurnal Syifa Al-Qulub dengan fokus kajian Psikoterapi Sufistik. Keenam, JAQFI, yakni Jurnal Aqidah dan Filsafat Islam.

Sumber daya fakultas meliputi dosen, mahasiswa, dan tata usaha. Dosen 145 orang, mahasiswa aktif 3.417 orang, dan tata usaha 46 orang. Kulifikasi dosen mencakup profesor, doktor, dan magister. Tiap tahun fakultas ini menerima mahasiswa baru sekitar 800 orang. Mahasiswa kebanyakannya lulusan madrasah dan pesantren, yang tersebar di wilayah nusantara, khususnya Jawa Barat. Alumni fakultas ini sebagian melakukan studi lanjut ke pascasarjana. Sebagian lagi ada yang menjadi pegawai negeri sebagai 
dosen, guru, pengadministrasi, penyuluh agama Islam, dan lain-lain. Sebagian yang lainnya lagi banyak yang menjadi kiyai, tokoh agama, ustadz, penceramah, pengajar di lingkungan swasta, dan tidak sedikit yang menjalani profesi sebagai wiraswasta.

\section{Tradition of Scientific Research in Theology}

Penelitian menjadi bagian yang tidak bisa dilepaskan dari mandat Tri Dharma Pendidikan Tinggi di Indonesia. Tri Dharma meliputi pendidikan, penelitian, dan partisipasi masyarakat (Jannah, 2018). Fakultas Ushuluddin UIN Sunan Gunung Djati Bandung pada dasarnya memiliki tradisi penelitian yang kuat.

Fakultas ini mengemban tugas memelihara dan mengembangkan pengetahuan dasar Islam meliputi teologi Islam, filsafat Islam, dan tasawuf. Juga bertugas memelihara sumber Teks Suci Islam, yaitu Al-Qur'an dan Hadis. Fakultas ini juga mengenalkan agama-agama dunia. Dalam menjalankan tugas memelihara dan mengembangkan pengetahuan dasar Islam, fakultas ini menaruh perhatian pada bidang metodologi. Bidang ini diperlukan dalam memahami dan mendalami pengetahuanpengetahuan dasar Islam. Sifat metodologi terus berkembang, baik dikembangkan dari pengetahuan dasar Islam maupun meminjam dari perkembangan pengetahuan lain yang relevan. Seperti ilmu kebahasaan meliputi mantik, semantik, semiotik, dan hermeneutik dan ilmu-ilmu sosial mencakup sejarah, antropologi, sosiologi, genealogi, dan lain-lain (Lubis, 2015).

Paling tidak, ada tiga bentuk penelitian yang dikembangkan di fakultas ini, yakni penelitian normatif (Muhajir, 2018), penelitian pemikiran (Halim, 2001), dan penelitian sosial-keagamaan (Rakhman, 2013). Penelitian normatif merupakan pemahaman terhadap dogma agama Islam. Penelitian normatif berlangsung sejak fakultas ini berdiri pada 1968 sampai tahun 1980-an. Penelitian bentuk ini merupakan konsekuensi logis dari peran Fakultas Ushuluddin dalam menjaga norma Islam di Indonesia. Pada tahun 1990-an fakultas ini mulai mengembangkan penelitian pemikiran. Penelitian ini dilandasi pandangan bahwa Islam bukan sebatas fakta normatif yang sakral, melainkan ia memiliki dimensi profan sehingga dapat dipikirkan secara rasional. Model penelitian ini mendapat pengaruh besar dari perkembangan wacana kritis era posmodernisme. Penelitian sosialkeagamaan muncul belakangan setelah era 1990-an. Model ini dimulai ketika para akademisi dosen meneruskan studi lanjut doktoral dan magister di program ilmu-ilmu sosial. 
Selain itu, muncul model penelitian baru sekitar tahun 2010-an, yaitu model penelitian yang dibawa dari tradisi sains. Tradisi ini menganut jenis penelitian kuantitatif dengan menerapkan observasi. Model ini dipengaruhi oleh akademisi sains dan teknologi. Hal ini sejalan dengan perubahan (Mujahidah \& Wekke, 2019) UIN Sunan Gunung Djati yang dirintis sejak tahun 2005 dengan paradigma WMI (Nanat Fatah Natsir, 2006). Semula bernama IAIN, namun model baru ini belum menemukan bentuknya di Fakultas Ushuluddin hingga 2021. Ini merupakan pertemuan dari dua kutub yang berbeda (Nugraha, 2020). Rumpun agama merupakan kutub materi dasar. Sedangkan rumpun sains merupakan kutub materi terapan.

Akademisi teologi Islam sempat mengalami "kekagetan" ketika menerima pengaruh dari perkembangan metodologi ilmu-ilmu sosial. Ada semacam pro dan kontra. Sebagian merasa harus menjaga pilar Islam dari tradisi normatif, dan sebagian lagi menghendaki perubahan pemikiran sebagai konsekuensi dari perkembangan baru metodologi ilmu-ilmu sosial. Penelitian pemikiran Islam mulai menerapkan statistik ketika metodologi ilmu-ilmu sosial memberikan pengaruh. Namun, statistik yang paling sederhana dengan tetap menempatkan basis penelitian pemikiran bukan pada jenis kuantitatif melainkan kualitatif. Penerapan statistik pada ilmu-ilmu sosial sendiri pada dasarnya dipengaruhi dari tradisi sains (Nurgiyantoro \& Gunawan, 2004). Penggunaan statistik di lingkungan akademisi teologi Islam bisa dikatakan belum tuntas. Di saat kondisi yang belum tuntas ini akademisi teologi Islam harus memahami model baru lagi dari tradisi rumpun ilmu terapan (Syukur, 2003). Praktis, Fakultas Ushuluddin mengalami "kekagetan" yang berlipat.

Fakultas Ushuluddin memiliki pekerjaan yang belum tuntas dalam menegaskan paradigama penelitian. Pada satu sisi memiliki tuntutan mempertahankan tradisi lama. Di pihak lain tidak bisa mengabaikan perkembangan baru. Hal ini bisa dikatakan sebagai posisi dilematis. Dalam posisi dilematis ini mesti segera diambil kebijakan yang tepat. Sebab, pradigma penelitian berimplikasi luas terhadap proses pendidikan dan partisipasi masyarakat yang menjadi mandat Tri Dharma Pendidikan Tinggi di Indonesia (Jannah, 2018).

\section{Islamic Theology in the Flow of Scientific Tradition}

Bidang sains dan teknologi tengah mengalami kemajuan di level dunia. Segala kebaikan di dunia ini harus berdasarkan petunjuk sains. Segala hal tidak ada yang 
terlepas dari pengaruh sains. Sebagai akibat dari kemajuan dunia sains dan teknologi maka hampir segala bidang diarahkan pada dunia terapan (Tim Penyusun, 2018).

Konsekuensi paling terburuk sempat muncul wacana sebaiknya Fakultas Ushuluddin dibubarkan saja. Setelah beralih dari IAIN menjadi UIN, Fakultas Ushuluddin sepi peminat. Minat mahasiswa baru ke fakultas paling tua ini tidak lebih banyak ketimbang ke fakultas umum. Lebih dramatis lagi fakultas ini terbelah menjadi beberapa fakultas, seperti Fakultas Dakwah, Fakultas Ilmu Sosial dan Politik (FISIP), dan ditambah lagi dengan adanya Fakultas Adab dan Humaniora. Sebagaimana kenyataan di Inggris, fakultas teologi mula pertama didirikan. Kemudian melebur menjadi fakultas humaniora. Bidang teologi menjadi mengecil sebatas program studi. Akan tetapi, Fakultas Ushuluddin di Indonesia berusaha tetap eksis. Meskipun pasti cukup berat mengingat penilaian akreditasi dari pemerintah diterapkan standar umum (Penyusun, 2019). Seperti kesiapan lulusan memasuki dunia kerja. Keharusan program studi berkerjasama dengan dunia industri. Serta kemestian berkompetisi dan berdaya saing secara terbuka.

Agama tetap dibutuhkan dilihat dari sistem keyakinan dan realitas. Agama menurut keyakinan pemeluknya tidak akan pernah hilang sampai langit runtuh. Realitanya, agama tetap bermain dalam peran-peran sosial, buadya, ekonomi, dan politik. Agama selalu hadir di tiap era tanpa kehilangan pemeluknya. Memang agama pernah ditinggalkan pada masa pencerahan yang terkenal era renaissance di Eropa (Menčik, 2020). Agama dituduh dogmatis, tidak rasional, dan candu. Agama dipandang sebagai penghambat pengembangan sains. Sehingga timbul para saintis tanpa agama. Namun, pemeluk agama semakin memantapkan langkah dan gerakan hingga mempengaruhi geo-politik, ekonomi, dan kebijakan. Saat ini tidak mungkin segala perubahan tanpa melibatkan agama.

Pada saat yang sama tradisi sains yang memiliki usia panjang juga menentukan segala hal. Kebenaran-kebenaran dari sains bersifat objektif dan tidak terbantahkan. Meskipun tidak jarang juga terjadi hipotesis-hipotesis yang salah. Cengkraman sains sangat kuat dalam berbagai kreatifitas, inovasi, dan perkembangan baru. Berbagai bidang dikerahkan menuju basis terapan. Seluruh sumber daya dipaksa memiliki keterampilan praktis. Bidang teologi tidak mungkin melakukan balapan dengan sains dan teknologi. Bidang ini memang sedang ada di depan melaju cepat. Jalan paling 
tepat tidak lain kolaborasi antara bidang teologi dan bidang sains (Rahmawati \& Thalia, 2012).

Di dunia teologi Islam dikenal apa yang disebut inter-disipliner, multi-disipliner, dan trans-disipliner. Inter-disipliner merupakan kajian antar-disiplin ilmu yang serumpun semisal teologi Islam, filsafat Islam, dan tasawuf. Multi-disipliner dipahami sebagai kajian lintas disiplin ilmu yang tidak serumpun seperti teologi Islam dan sosiologi. Trans-disipliner berarti penggabungan ilmu pengetahuan (Hadorn et al., 2008) seperti teologi dan sains. Hal terakhir bisa diwujudkan melalui kolaborasi antara akademisi teologi dengan akademisi sains. Hanya saja kolaborasi bidang materi dasar dan materi terapan baru sebatas kebijakan (Tim Penyusun, 2018). Adapun implementasi hal ini masih dalam tahap percobaan belum menghasilkan bentuk yang diharapkan.

Bidang sains dan tekonologi tetap masih terdepan. Hal ini bisa diukur melalui indikator pencapaian publikasi ilmiah. Akademisi bidang sains dan teknologi lebih unggul dalam publikasi ilmiah di UIN Sunan Gunung Djati Bandung. Perbandingan publikasi ilmiah antara bidang agama dan humaniora dengan bidang sains dan teknologi yakni 3 berbanding 10 (Darmalaksana, 2019a).
Jelas ini suatu ketertinggalan. Padahal, akademisi bidang sains dan teknologi tidak lebih banyak dibandingkan akademisi bidang agama dan humaniora di UIN Sunan Gunung Djati Bandung. Jelas ini suatu problem yang membutuhkan pemecahan serius. Publikasi ilmiah merupakan kewajiban akademisi dalam pelaksanaan Tri Dharma Pendidikan Tinggi. Dosen memiliki kewajiban mempublikasikan hasil kerja Tri Dharma di jurnal ilmiah.

Akademisi teologi Islam penting belajar dari tradisi sains dan teknologi. Di antaranya belajar menerapkan studi lapangan di samping studi pustaka meskipun dilaksanakan dalam basis jenis penelitian kualitatif. Ketika melaksanakan studi lapangan mungkin saja dilakukan pengamatan, dokumentasi, dan wawancara serta pengukuran sederhana dengan menerapkan statistik. Mungkin juga mixed method yang berusaha menggabungkan jenis kualitatif dan jenis kuantitatif (Johnson et al., 2007; Small, 2011). Namun, hal ini dibutuhkan penguasaan jenis penelitian kuantitatif di lingkungan akademisi teologi Islam sehingga dihasilkan karya-karya ilmiah multidisipliner. Selebihnya memungkinkan dilakukan kolaborasi yang menegaskan akademisi teologi tetap berbasis pada materi dasar dengan akademisi sains yang 
berbasis pada materi terpan. Sehingga dihasilkan karya-karya ilmiah transdisipliner.

Kolaborasi penting berlangsung dalam banyak hal. Penulisan artikel ilmiah sebagai bahan dasar publikasi mensyaratkan penerapan aplikasi (Muttaqin, 2020). Bahkan, ada berbagai aplikasi yang niscaya perlu diterapkan sejak dimulai pelaksanaan penelitian bagi kepentingan pengolahan data. Penguasaan berbagai aplikasi sejak penelitian hingga penulisan artikel ilmiah menjadi tugas kalangan akademisi sains dan teknologi. Diketahui bahwa jurnal ilmiah mensyaratkan penulisan artikel ilmiah dihasilkan dari penelitian. Sedangkan sejak penelitian hingga penulisan artikel ilmiah tidak terlepas dari keharusan penerapan berbagai aplikasi. Pada saat yang sama jurnal ilmiah pun telah bergeser dari sistem cetak ke sistem elektronik. Pada gilirannya pelaksanaan koresponden dengan jurnal ilmiah sistem elektronik ini dibutuhkan adaptasi teknologi. Segala hal telah serba digital sehingga dibutuhkan literasi teknologi. Penerapan berbagai aplikasi teknologi merupakan perkara yang membutuhkan adaptasi yang tidak sederhana bagi kalangan akademisi bidang teologi. Pantas, publikasi ilmiah di lingkungan akademisi sains dan teknologi mengalami akselerasi yang cepat. Oleh karena itu, penguasaan berbagai aplikasi menjadi tanggungjawab akademisi bidang sains dan teknologi. Kolaborasi bagi pembagian peran menjadi hal yang penting (López-Pellisa et al., 2020).

Sementara itu, temuan-temuan sains dan teknologi pun idealnya tetap tidak melepaskan diri dari teori-teori abstrak. Teori abstrak mencakup pula teori-teori teologis. Teori abstrak disebut pula grand theory yang dalam teologi Islam diasalkan dari sumber-sumber Suci, Teks Al-Qur'an dan Hadis, melalui metodologi interpretasi. Akademisi bidang teologi Islam tidak semestinya hanya terus bermain-main di dalam teori abstrak. Mereka harus turun dari langit ke bumi (Nurhayati, 2018). Ketika turun dari langit ke bumi dengan membawa pesan-pesan moral Teks Suci dibutuhkan middle theory. Adapun middle theory ini merupakan jembatan antara grand theory dan aplicative theory. Teori yang disebutkan terakhir ini merupakan milik para akademisi bidang rumpun ilmu materi terapan. Hal yang ingin ditegaskan di sini adalah materi terapan pasti membutuhkan pijakan materi dasar. Jika materi terapan tanpa pijakan dasar, maka keropos, ambruk, dan relatif. Dalam hal ini, akademisi sains dan teknologi pun membutuhkan teori-teori teologis. 
Antara teologi dan sains hampir tidak ada titik temu. Ideologi keterpisahan ini tidak tepat diteruskan bagi kebaikan dunia (Zaluchu, 2018). Bisa saja terjadi saintis sangat agamis tanpa melibatkan teologi dalam produksi sains. Ini terjadi akibat ideologi keterbelahan. Kolaborasi merupakan jalan menyatukan keterbelahan. Juga langkah mengarahkan mahasiswa generasi milenial pada literasi teknologi dan berbagai aplikasi dapat dipahami sebagai upaya memperkecil keterpisahan. Meskipun mereka merupakan mahasiswa peminat teologi Islam, walaupun mereka lulusan madrasah dan pesantren, mahasiswa generasi milenial ini sangat adaptif terhadap pengguanaan berbagai aplikasi. Saatnya mahasiswa bidang teologi Islam diberi kesempatan mengases teknologi secara lintas batas bagi kepentingan penguatan kapasitas penulisan artikel di jurnal ilmiah. Pada gilirannya solusi pencapaian publikasi ilmiah bidang teologi Islam terpecahkan melalui peran serta mahasiswa.

Selain sebagai sebuah kewajiban bagi akademisi, publikasi di jurnal ilmiah juga merupakan kebutuhan. Sebab, publikasi di jurnal ilmiah mempunyai implikasi yang luas. Ia merupakan pencapaian penelitian, penulisan artikel ilmiah, dan kontribusi pengetahuan. Publikasi ilmiah akan dibaca khalayak, sumber rujukan bagi pengajaran dan partisipasi masyarakat, dan pengambilan keputusan di kalangan penentu kebijakan (Jannah, 2018). Akademisi teologi Islam mesti bangkit dari ketertinggalan dalam pencapaian publikasi ilmiah sebagai banyak dihasilkan oleh kalangan akademisi sains dan teknologi.

\section{Problem Solving Islamic Theology Scientific Publications Based on FGD}

Berbagai kendala publikasi ilmiah menjadi materi FGD di Fakultas Ushuluddin UIN Sunan Gunung Djati Bandung. FGD dipahami sebagai salah satu metode efektif dalam pemecahan masalah. FGD menghasilkan beberapa poin rekomendasi.

\section{a. Regulasi dan Tata Kelola}

Penguatan kapasitas penulisan dan publikasi ilmiah membutuhkan regulasi yang menjadi dasar kebijakan (Yamin, 2018). Regulasi terstruktur mulai dari tingkat kementerian, universitas, dan fakultas. Turunan dari regulasi dibutuhkan rencana strategis, manual, prosedur, dan instruksi kerja. Adapun implementasi dari berbagai dokumen input tersebut dibutuhkan tata kelola yang baik. Fungsi tata kelola meliputi pembuatan dan pengembangan sistem, pelaksanaan kegiatan, 
evaluasi, dan eksekusi. Tata kelola dibentuk hingga unit terkecil berupa organisasi penanggungjawab publikasi ilmiah (Darmalaksana, 2018).

\section{b. Pemetaan dan Pengembangan Sumber Daya}

Pendidikan tinggi memiliki tugas utama pengembangan sumber daya.

Berkenaan dengan penguatan kapasitas penulisan dan publikasi ilmiah dibutuhkan pemetaan sumber daya. Pemetaan ini meliputi sumber daya peneliti, penulis artikel ilmiah, pengelola jurnal, dan tata usaha. Seluruh sumber daya dilatih, diposisikan dalam peran-peran strategis, dan berkerja secara profesional.

\section{c. Pelaksanaan Kegiatan Kelas Menulis}

Pelembagaan pusat penulisan bernama Kelas Menulis yang berperan memberikan bantuan penulisan artikel ilmiah bagi akademisi, baik dosen maupun mahasiswa (Penyusun, 2020). Pada Kelas Menulis disiapkan panduan penulisan artikel ilmiah yang dikembangkan oleh laboratorium dan pengelola jurnal ilmiah. Panduan ini berfungsi sebagai acuan bagi pelatihan menulis artikel ilmiah. Di Kelas Menulis disiapkan pelatih profesional di bidang penulisan artikel ilmiah. Pelatih berperan melakukan pendampingan dalam latihan penulisan artikel ilmiah. Juga melakukan introgasi keseuaian antara penulisan hasil latihan dengan panduan penulisan artikel ilmiah. Pelaksanaan latihan dilakukan treatment melalui reviu terhadap naskah artikel sebagai umpan balik dalam memastikan peningkatan kualitas tulisan (Org, 2019). Materi Kelas Menulis mencakup pula pelatihan penyusunan proposal penelitian dan sekaligus pelaksanaan penelitian.

\section{d. Memastikan Pencapaian dan Evaluasi}

Pelaksanaan Kelas Menulis mentargetkan kesuksesan dan keberhasilan. Indikator sukses yaitu tercapainya penulisan artikel ilmiah secara tuntas. Indikator berhasil yakni tercapainya publikasi bidang teologi Islam di jurnal ilmiah. Pencapaian publikasi ilmiah dapat dilalui melalui kepesertaan dalam konferensi sebagai presenter artikel ilmiah. Dan melalui pengiriman naskah artikel ke jurnal ilmiah reguler. Naskah artikel dapat berupa prosiding dan artikel ilmiah 
lengkap. Artikel ilmiah dapat berupa

hasil penulisan bersama antara dosen muda dan dosen senior atau antara dosen dan mahasiswa (López-Pellisa et al., 2020). Dipastikan penulisan artikel ilmiah secara bersama mencakup urutan penulis utama, penulis korespondensi, dan penulis pendamping. Perlu dilakukan pula evaluasi target dengan pencapaian.

e. Analisis Peran-peran Stakeholdes

Fakultas Ushuluddin UIN Sunan Gunung Djati Bandung melingkupi sistem struktur. Di dalam sistem struktur terdapat peran-peran stakeholders. Peran ini perlu dianalisis kaitannya dengan penyelenggaraan Kelas Menulis menyangkut pengaruh, perhatian, dan dukungan. Seluruh stakeholders berserta peran mereka mesti diupayakan hingga memberikan dukungan riil. Sebab, sukses Kelas Menulis sangat bergantung pada dukungan. Hal ini menyangkut pula dukungan finansial bagi kebutuhan proses, insentif, dan penghargaan (Darmalaksana, 2019b). Kelas Menulis akan mencakup banyak proses dari hulu ke hilir, pembiayaan personalia profesional, dan penghargaan bagi akademisi produktif dan berprestasi. Pembiayaan dapat diperoleh dari biaya operasional, beasiswa, dan sponsor.

Bermula dari subjek publikasi ilmiah sebagai tantangan akademisi bidang teologi Islam di Fakultas Ushuluddin UIN Sunan Gunung Djati Bandung. Kemudian ditelusuri berbagai faktor kendala dan hambatan. Selanjutnya, pemecahan masalah ditempuh melalui FGD. Hal ini bukan saja diharpkan tercipta penguatan kapasitas penulisan artikel ilmiah, akselerasi publikasi akademisi teologi Islam di jurnal ilmiah, melainkan diharapkan pula terwujud kultur akademik yang kondusif di bidang pendidikan, penelitian, dan partisipasi masyarakat. Dengan tidak bermaksud melakukan generalisasi, meskipun hal ini merupakan kasus penguatan publikasi ilmiah di lingkungan akademisi teologi Islam pada Fakultas Ushuluddin UIN Sunan Gunung Djati Bandung, namun dimungkinkan pula dilakukan pengujian bagi penerapan pada pendidikan tinggi Islam di Indonesia. 


\section{CONCLUSION}

Publikasi ilmiah akademisi teologi Islam tertinggal jauh oleh akademisi sains dan teknologi. Kenyataan ini menjadi tantangan sekaligus peluang bagi akademisi teologi Islam dalam pengembangan teologi Islam terapan berbasis tradisi penelitian sains. Pada saat yang sama hal ini pun sebagai peluang bagi akademisi sains dan teknologi dalam perumusan penelitian berbasis teori teologi Islam. Sehingga tercipta hasil penelitian, penulisan artikel, dan publikasi ilmiah dalam bentuk mulidisipliner dan trans-disipliner. Tercipta pula kolaborasi antara bidang teologi Islam dan bidang sains dan teknologi dalam percepatan publikasi di jurnal ilmiah. Bagi pengelolaan bidang teologi Islam sendiri penting pula menegaskan kembali arah kebijakan dan tata kelola publikasi ilmiah, pemetaan dan penguatan sumber daya penulisan artikel ilmiah secara profesional, penyelenggaraan pusat penulisan, memastikan kesuksesan dan keberhasilan serta pelaksanaan evalusi, dan analisis peran-peran stakeholders. Dihararapkan hasil penelitian ini bermanfaat bagi pengembangan publikasi ilmiah bidang teologi Islam. Keterbatasan penelitian hanya berupa studi kasus di salah satu fakultas di pendidikan tinggi keagamaan Islam, sehingga diperlukan penelitian lebih lanjut dalam menelaah kasus-kasus di tempat lain. Penelitian ini merekomendasikan kepada pengampu kebijakan agar publikasi ilmiah bidang teologi Islam mendapat perhatian serius di lingkungan pendidikan tinggi keagamaan Islam di Indonesia.

\section{REFERENCES}

Adnan, Z. (2005). Merebut Hati Audiens Internasional: Strategi Ampuh Meraih Publikasi di Jurnal Ilmiah. Gramedia Pustaka Utama.

Afwadzi, B. (2016). Memahami Eksistensi Pendekatan Ilmu-ilmu Alam dan Pemahaman Hadis Nabi.

Afwadzi, B. (2017). Integrasi Ilmu-Ilmu Alam dan Ilmu-Ilmu Sosial Dengan Pemahaman Hadis Nabi: Telaah atas konsepsi, aplikasi, dan implikasi. Theologia, 28(2), 351-390.

Anggito, A., \& Setiawan, J. (2018). Metodologi penelitian kualitatif. CV Jejak (Jejak Publisher).

Asmiati, A. (2020). Strategi Publikasi Jurnal Adabiyah Universitas Islam Negeri Alauddin Makassar. Universitas Islam Negeri Alauddin Makassar.

Aziz, A. (2013). Paradigma Integrasi Sains Dan Agama Upaya Transformasi Iain Lampung Kearah UIN. Al-Adyan: Jurnal Studi Lintas Agama, 8(2), 6790.

Badarussyamsi, B. (2015). Spiritualitas Sains Dalam Islam: Mengungkap Teologi Saintifik Islam. MIQOT: Jurnal Ilmu-Ilmu Keislaman, 39(2).

Bahri, S. (2012). Perubahan Paradigma Keilmuan IAIN Menuju UIN ArRaniry. Jurnal Ilmiah Islam Futura, 
11(2), 38-52.

Basri, H. (2019). Teologi Sains: Mengatasi Dikotomi Sains-Agama Perspekif Islam. Jurnal Pemikiran Islam, 5(2).

Darda, A. (2016). Integrasi ilmu dan agama: Perkembangan konseptual di Indonesia. At-Ta'dib, 10(1).

Darmalaksana, W. (2017a). Analisis Kultur Penelitian dan Publikasi UIN Sunan Gunung Djati Bandung.

Darmalaksana, W. (2017b). Membudayakan group penulisan artikel untuk percepatan publikasi ilmiah.

Darmalaksana, W. (2018). Organisasi Penanggungjawab Publikasi Hasil Penelitian.

Darmalaksana, W. (2019a). Analisis Peningkatan Publikasi Ilmiah Pendidikan Tinggi Keagamaan Islam di Indonesia. Pusat Studi Data Ushuluddin UIN Bandung.

Darmalaksana, W. (2019b). Strategi Penganggaran Penelitian dan Publikasi Ilmiah.

Darmalaksana, W. (2020). Metode Penelitian Kualitatif Studi Pustaka dan Studi Lapangan. Pre-Print Digital Library UIN Sunan Gunung Djati Bandung.

Darmalaksana, W., Aziz, W. D. I., Rahmatullah, S., Irwansyah, F. S., Sugilar, H., Maylawati, D. S., \& Suhendi, H. Y. (2018). Analisis Ranking Produktivitas Publikasi Ilmiah Berbasis h-Index Google Scholar.

Fadhilaturrahmi, F., Erlinawati, E., \& Ananda, R. (2020). Workshop Sinta 2 dan Google Schoolar di Universitas Pahlawan Tuanku Tambusai. Jurnal Abdidas, 1(4), 203-209.

Falah, S. (2019). Pelatihan Mendeley dan
Anti-Plagiat untuk Meningkatkan Kualitas Karya Ilmiah Mahasiswa. THE COMMUNITY ENGAGEMENT JOURNAL, 2(2), 1-5.

Fernandez, D., Merina, M., \& Susilo, S. (2020). Pelatihan Teknik Sitasi dan Pencarian Referensi untuk Meningkatkan Publikasi Ilmiah di Universitas Muhammadiyah Sumatera Barat. Jurnal SOLMA, 9(1), 113-120.

Firmansyah, A., Qadri, R. A., \& Arham, A. (2020). Pelatihan melalui Web Seminar terkait Publikasi Artikel untuk Menembus Jurnal Sinta 2 dan Scopus. Abdimas: Jurnal Pengabdian Masyarakat Universitas Merdeka Malang, 5(2), 131-138.

Gray, R., \& Hoyt, J. (2020). Changing Attitudes: Impact of Mandatory Tutoring in Writing Centers. Curiosity: Interdisciplinary Journal of Research and Innovation, 1(1), 12711.

Hadorn, G. H., Hoffmann-Riem, H., BiberKlemm, S., Grossenbacher-Mansuy, W., Joye, D., Pohl, C., Wiesmann, U., \& Zemp, E. (2008). Handbook of transdisciplinary research (Vol. 10). Springer.

Halim, A. (2001). Teologi Islam rasional: Apresiasi terhadap wacana dan praksis Harun Nasution. Ciputat Press.

Hasbiansyah, O. (2008). Pendekatan fenomenologi: Pengantar praktik penelitian dalam Ilmu Sosial dan Komunikasi. Mediator: Jurnal Komunikasi, 9(1), 163-180.

Ina, A. A., \& Yulianti, N. R. (2020). Pelatihan Implementasi Science and Technology Index (SINTA). Jurnal Berdaya Mandiri, 2(1), 285-294.

Istikomah, I. (2019). Integrasi Sains dan Agama Di Perguruan Tinggi Sebagai Upaya Mengikis Dikotomi Ilmu. Tadrisuna: Jurnal Pendidikan Islam dan Kajian Keislaman, 2(1), 66-78. 
Jannah, M. (2018). Strategi Peningkatan Publikasi Ilmiah di Universitas Gadjah Mada. JIPI (Jurnal Ilmu Perpustakaan Dan Informasi), 3(2), 238-248.

Johnson, R. B., Onwuegbuzie, A. J., \& Turner, L. A. (2007). Toward a definition of mixed methods research. Journal of Mixed Methods Research, 1(2), 112-133.

Junipriansa, D. (2020). Manajemen Pengetahuan, Manajemen Bakat, dan Dukungan Organisasi Pengaruhnya terhadap Kinerja Dosen dalam Publikasi Ilmiah dengan Keterlibatan Dosen sebagai Variabel Moderasi pada Dosen Fakultas Ekonom.

Kartimi, K., \& Mulyani, A. (2016). Analisis Kesiapan Sumber Daya IAIN terhadap Perubahan Status Menjadi UIN Syekh Nurjati Cirebon. Holistik, 1(1).

Kurniasih, N., Hasyim, C., Wulandari, A., Setiawan, M. I., \& Ahmar, A. S. (2018). Comparative case studies on Indonesian higher education rankings. Journal of Physics: Conference Series, 954(1), 12021.

Lobner, J., \& As, C. O. (n.d.). COVID 19 \& Its Implications For The Writing Center.

López-Pellisa, T., Rotger, N., \& RodríguezGallego, F. (2020). Collaborative writing at work: Peer feedback in a blended learning environment. Education and Information Technologies, 1-18.

Lubis, M. R. (2015). Pendekatan Ilmu-Ilmu Sosial Dalam Studi Perbandingan Agama. Ushuluna: Jurnal Ilmu Ushuluddin, 1(1), 19-39.

Lukman, F. (2017). Integrasi-Interkoneksi dalam Studi Hadis Disertasi Di UIN Sunan Kalijaga Yogyakarta. RELIGIA, $1-11$.

Mahmud, M., \& Arafah, R. N. (2020). Air
Zam-zam dalam Perspektif Hadis dan Sains (Upaya Mendamaikan Agama dan Sains). Prosiding Konferensi Integrasi Interkoneksi Islam Dan Sains, 2, 219-223.

Mahyudi, D. (2016). Pendekatan Antropologi Dan Sosiologi Dalam Studi Islam. Ihya Al-Arabiyah: Jurnal Pendidikan Bahasa dan Sastra Arab, 2(2).

Mardin, H., Baharuddin, B., \& Nane, L. (2020). Pelatihan Cara Menulis Sitasi Dan Daftar Pustaka Jurnal Format Apa StyleMenggunakan Aplikasi Mendeley. Jurnal Abdidas, 1(3), 137143.

Maryono, M., \& Surajiman, S. (2017). Kolaborasi Internal, Domestik dan Internasional Serta Korelasinya dengan Sitasi yang Diperoleh: Analisis Publikasi UGM di Scopus. Berkala Ilmu Perpustakaan Dan Informasi, 13(2), 166-177.

McMillan, L., Johnson, T., Parker, F. M., Hunt, C. W., \& Boyd, D. E. (2020). Improving Student Learning Outcomes through a Collaborative Higher Education Partnership. International Journal of Teaching and Learning in Higher Education, 32(1), 117-124.

Menčik, D. (2020). Perspectivism of Renaisance Thought. Doi: Http://Dx. Doi. Org/10.12681/Eml, 22101.

Misbah, J. (2019). Transformasi Stain Ke UIN Dilema dan Prospektif. Foramadiahi, 10(2), 121-138.

Muhajir, M. (2018). Pendekatan Teologis Normatif. Jurnal An-Nawa, 15(2).

Mujahidah, M., \& Wekke, I. S. (2019). Transformasi Perguruan Tinggi Keagamaan Islam Indonesia.

Mujiburrahman, M. (2017). Dari IAIN ke UIN Pangeran Antasari: Tantangan dan Peluang di Tengah Arus Perubahan 
Sosial dan Budaya. Khazanah: Jurnal Studi Islam Dan Humaniora, 12(1).

Muksin, M. (2019). Perubahan Status Kelembagaan Perguruan Tinggi Agama Islam: Studi Perubahan Iain menjadi UIN dan STAIN menjadi IAIN. Jurnal Kelola: Jurnal Ilmu Sosial, 2(2), 70-84.

Murtadlo, M. (2020). Penguatan Publikasi Internasional Kajian Keagamaan Melalui Call for Paper.

Muttaqin, I. (2020). Supervision Planning at Islamic Education Institutions: Google Scholar Library Studies and Mendeley's Reference Manager. Istawa: Jurnal Pendidikan Islam, 5(2), 222-238.

Natsir, N F. (2013). Paradigma Wahyu Memandu Ilmu dalam Pembidangan Ilmu-Ilmu Keislaman. Tersedia Online: Http://Www. Uinsgd. Ac. Id/Front/Detail/Mengenal_tokoh/Nana t-Fatah-Natsir.

Natsir, Nanat Fatah. (2006). Pandangan Keilmuan UIN, Wahyu Memandu Ilmu. Bandung: Gunung Djati Press.

Nugraha, M. T. (2020). Integrasi Ilmu dan Agama: Praktik Islamisasi Ilmu Pengetahuan Umum di Perguruan Tinggi. Al-Hikmah: Jurnal Agama Dan Ilmu Pengetahuan, 17(1), 29-37.

Nurgiyantoro, B., \& Gunawan, M. (2004). Statistik terapan untuk penelitian ilmuilmu sosial. Cetakan Ketiga (Revisi), PT Gramedia Pustaka Utama, Jakarta.

Nurhayati, N. (2018). Kontekstualisasi Teologi Islam sebagai Basis Regulasi Ekologi Transendensi.

Org, A. (2019). The process of essay writing in a literature course: the student's views and the tutor's feedback. Estonian Journal of Education/Eesti Haridusteaduste Ajakiri, 7(2).
Penyusun. (2020). Surat Keputusan Dekan Fakultas Ushuluddin Universitas Islam Negeri Sunan Gunung Djati Bandung Nomor: $B$ 875/Un.05/III.1/PP.00.9/05/2020 tentang Penetapan Pedoman Kelas Menulis Fakultas Ushuluddin UIN Sunan Gunung Djati Bandung. http://digilib.uinsgd.ac.id/31086/

Penyusun, T. (2019). Rencana Strategis Fakultas Ushuluddin UIN Sunan Gunung Djati Bandung Periode 2019 2023. Fakultas Ushuluddin UIN Sunan Gunung Djati Bandung.

Perdana, F. J. (2020). Pelatihan Membuat Daftar Pustaka Otomatis Dengan Aplikasi Mendeley Desktop Bagi Mahasiswa Dalam Persiapan Penyusunan Tugas Akhir. Dimasejati: Jurnal Pengabdian Kepada Masyarakat, 2(1), 75-93.

Petrykowski, A. (2020). Unexplored Conceptions: What Writing Center Tutors Think about Writing.

Putra, Y. Y., \& Saputra, A. (2019). Workshop Publikasi Artikel Ilmiah dalam Jurnal Nasional Guru SMP Pangkalpinang. JPMB: Jurnal Pemberdayaan Masyarakat Berkarakter, 2(2), 207-215.

Rahmawati, L. E., \& Thalia, N. (2012). Upaya Meningkatkan Kemampuan Menulis Ilmiah Mahasiswa S1 Fisioterapi UMS dengan Metode Kolaborasi Pada Tahun Akademik 2012/2013. Jurnal Penelitian Humaniora, 13(2), 178-189.

Rakhman, A. B. (2013). Teologi Sosial; Keniscayaan Keberagamaan yang Islami Berbasis Kemanusiaan. ESENSIA: Jurnal Ilmu-Ilmu Ushuluddin, 14(2), 161-182.

Raya, M. K. F. (2017). Model Pengembangan Keilmuan UIN Malang dan UIN Yogyakarta. FALASIFA: 
Jurnal Studi Keislaman, 8(1), 65-82.

Rohmatika, R. V. (2019). Pendekatan Interdisipliner dan Multidisipliner Dalam Studi Islam. Al-Adyan: Jurnal Studi Lintas Agama, 14(1), 115-132.

Rosa, S. A. S., Irawati, I., Saefullah, D., \& Myrna, R. (2020). Partnership Dalam Produktivitas Publikasi Hasil Penelitian di Lembaga Ilmu Pengetahuan Indonesia. Jurnal Administrasi Publik, 11(1).

Saifudin, S. (2020). Integrasi Ilmu Agama Dan Sains: Studi Penulisan Skripsi Di UIN Syarif Hidayatullah Jakarta. Profetika: Jurnal Studi Islam, 21(1), 78-90.

Schell-Barber, L. A. (2020). Writing Centers between Past and Future: Outstanding Scholarship Award Texts and Student Success. Kent State University.

Shodiq, M. (2018). Pendekatan Tafsir Modern Interpretasi Teologis, Kultural, dan Logis. Al-Burhan| Jurnal Kajian Ilmu Dan Pengembangan Budaya AlQur'an, 18(2).

Siemann, C. (2020). Writing Center Continuity Plan.

Situmorang, M., \& Sihombing, K. (2018). Strategi Mempersiapkan Manuscript Artikel yang Baik untuk Publikasi pada Jurnal Ilmiah Bereputasi. GENERASI KAMPUS, 10(2).

Small, M. L. (2011). How to conduct a mixed methods study: Recent trends in a rapidly growing literature. Annual Review of Sociology, 37.

Subekti, N. B. (2018). Rangking Publikasi Ilmiah Internasional Indonesia.

Sudikan, S. Y. (2015). Pendekatan interdisipliner, multidisipliner, dan transdisipliner dalam studi sastra. Paramasastra, 2(1).
Sugilar, H., Priatna, T., \& Darmalaksana, W. (2019). Strategi Perguruan Tinggi dalam meningkatkan Publikasi Hasil Penelitian. Al-Fikrah: Jurnal Manajemen Pendidikan, 7(1), 45-50.

Suharto, T. (2018). Pemetaan Ayat-Ayat alQur'an tentang Rumpun Ilmu Agama dalam Perspektif Paradigma IntegrasiInterkoneksi. Intizar, 24(1), 83-102.

Suratman, S., \& Eriyanti, E. (2020). Peningkatan Sumber Daya Manusia Melalui Pelatihan. Prosiding Seminar Nasional Program Pascasarjana Universitas PGRI Palembang.

Suryadilaga, M. A. (2007). Implementasi Pendekatan Integrasi-Interkoneksi dalam Kajian Living Hadis. Islamic Studies dalam Paradigma IntegrasiInterkoneksi: Sebuah Antologi

Syukur, M. A. (2003). Teologi Islam terapan: upaya antisipatif terhadap hedonisme kehidupan modern. Tiga Serangkai.

Tim Penyusun. (2018). Keputusan Direktur Jenderal Pendidikan Islam Nomor 6994 Tahun 2018 tentang Agenda Riset Keagamaan Nasional (Arkan) 20182028.

Tim Penyusun. (2019). Keputusan Direktur Jenderal Pendidikan Islam Nomor 2498 Tahun 2019 tentang Pedoman Implementasi Integrasi Ilmu di PTKI.

Triyanto, T., Yana, R. H., \& Nurkhalis, N. (2020). Sosialisasi Mendeley Pada Mahasiswa Universitas Teuku Umar. Jurnal Pengabdian Masyarakat: Darma Bakti Teuku Umar, 2(1), 7-21.

Viale Pereira, G., Cunha, M. A., Lampoltshammer, T. J., Parycek, P., \& Testa, M. G. (2017). Increasing collaboration and participation in smart city governance: a cross-case analysis of smart city initiatives. Information Technology for Development, 23(3), 526-553. 
Wekke, I. S. (2019). Menulis Artikel untuk

Publikasi di Jurnal Bereputasi.

Yamin, M. (2018). Kebijakan Literasi Untuk Meningkatkan Produktivitas Publikasi di Perguruan Tinggi. JAS-PT (Jurnal Analisis Sistem Pendidikan Tinggi Indonesia), 2(1), 19-26.

Zainiyati, H. S. (2015). Landasan Fondasional Integrasi Keilmuan di UIN
Maulana Malik Ibrahim Malang dan UIN Sunan Ampel Surabaya. Islamica: Jurnal Studi Keislaman, 10(01), 248276.

Zaluchu, S. E. (2018). Mengkritisi Teologi Sekularisasi. KURIOS (Jurnal Teologi Dan Pendidikan Agama Kristen), 4(1), 26-38. 
